\title{
AERATION - ADVANCED FILTRATION (AAF) TREATMENT FOR REDUCING IRON AND CHLORIDE IN NATURAL GROUNDWATER
}

\author{
Nur Aini Febriyana I Ali Masduqi*
}

Department of Environmental Engineering, Institut Teknologi Sepuluh Nopember, Surabaya, Indonesia

\section{Correspondence}

*Ali Masduqi, Department of Environmental Engineering, Institut Teknologi Sepuluh Nopember, Surabaya, Indonesia. Email: masduqi@its.ac.id

\section{Present Address}

Gedung Teknik Lingkungan, Kampus ITS Sukolilo, Jl. Raya ITS, Surabaya 60111, Indonesia

\begin{abstract}
The production of drinking water for the needs of rural communities generally still depend on natural water sources. Communities in rural areas usually use groundwater for their daily needs. The water supply in Sampang Regency, East Java Province has groundwater problem, i.e. the amount of iron and chloride in the water supply exceed the maximum amount allowed by PERMENKES No. 492/2010. Therefore, this study proposes a method for drinking water treatment using diffused aeration, as pretreatment, and followed by filtration processing. This pretreatment is meant for reducing iron. The filtration process is carried out in stages with an advanced filter of low continuous discharge. The filter media uses resin activated carbon and microfiltration to remove suspended and dissolved ions. The results of aeration and filtration processing (AAF) shows that the preprocessed water have Cl-removal of $98.39 \%$, TDS-removal of $97.394 \%$, and iron-removal of $97.41 \%$.
\end{abstract}

\section{KEYWORDS:}

Advance Filtration, Aeration, Natural Groundwater, Water Treatment

\section{1 | INTRODUCTION}

One source of water that the community widely used is groundwater. Nevertheless, not all groundwater meet the drinking water quality requirements ${ }^{11}$. On the other hand, due to changes in ecosystems in natural water sources and poor local water conditions, water quality decreases and not suitable to be used for household purposes, especially used as drinking water ${ }^{[2]}$.

Most people in rural areas use groundwater for their daily needs. Frequently, this water contains high iron minerals with high chloride concentrations and other pollutants. The groundwater smells smell fishy during the dry season because it comes from groundwater with iron content and a little salty (brackish) due to chloride. Meanwhile, water-containing iron and too high salinity are harmful if used for certain activities, such as health problems when used as drinking water, causing crop failures 
for agriculture, corrosion of equipment, and buildings made of metal elements. The content of excess mineral salts consumed continuously by humans results in adverse effects on human health.

The factor that can influence the low quality of dug well water includes season, construction, type and slope of the land, distance from sources of contamination, and behavior of living things around it. During the hydrological cycle, the water always absorbs substances that cause the water to be no longer pure. Therefore, in essence, there is no truly pure water. Substances absorbed by natural water can be classified as dissolved solids, dissolved gases, and suspended solids. In general, the type of impurity contained in water depends on the kind of material that is in contact with the water, while the amount of impurity depends on the time of $\operatorname{contact}^{11}$.

The water used by the community must meet the quality standards in sanitation in the Regulation of the Minister of Health of the Republic of Indonesia No. 32 of 2017, especially for drinking water. Drinking water consumed by the public must meet the government's parameters, namely the Regulation of the Ministry of Health of the Republic of Indonesia No. 492/Menkes/SK/IV/2010 concerning Drinking Water Quality Requirements 3 .

Based on laboratory tests' results for the quality of groundwater from several water-supplies in Sampang Regency containing dissolved ions such as iron, hardness chloride, and others. The water used by the community must meet the government's drinking water quality standards, namely the Regulation of the Ministry of Health of the Republic of Indonesia No. 492/Menkes/SK/IV/2010 concerning Drinking Water Quality Requirements. Some water supply in Sampang Regency exceeds the quality standard of PerMenKes 492/2010, reaching TDS 2,890-7,560 mg/L in the quality standard of $500 \mathrm{mg} / \mathrm{L}$, iron 1-3 $\mathrm{mg} / \mathrm{L}$ at the standard quality of $0.3 \mathrm{mg} / \mathrm{L}$, and chloride until $6,400 \mathrm{mg} / \mathrm{L}$ in quality standard $250 \mathrm{mg} / \mathrm{L}$.

Parameters contained in the groundwater is high iron and chloride. There are also other parameters, such as TDS. On the other hand, the state of soil in clay containing limestone can affect groundwater's $\mathrm{pH}^{\mathbb{4} 4}$. However, a comfortable and systematic treatment method can ensure that the water supplied is safe and clean to be used by consumers.

For this reason, technology selection to reduce iron and chloride content in groundwater. One of the most suitable water treatment techniques for iron and chloride removal is aeration and filtration. Aeration is the process of treating water by contacting it with air. The purpose of this aeration is to increase the amount of dissolved oxygen, decrease the amount of $\mathrm{CO}$, eliminate $\mathrm{H} 2 \mathrm{~S}$, $\mathrm{CH} 4$, which causes odor, reduces $\mathrm{Fe}$ and $\mathrm{Mn}$ in water.

A diffused-air aerator is a process in which a certain amount of air is diffused into raw water through high pressure into the tank/treatment tank. Air infused will oxidize some compounds that can be removed by the oxidation process. This process is usually used in groundwater, which mostly has low dissolved oxygen content. Therefore, aeration in this application will produce sediment and increase dissolved oxygen concentration. Filtration is the separation of solids and liquids where liquid passes through porous media or other porous material to remove as much as possible suspended solids. This is used in water treatment to filter coagulated and precipitated chemicals to produce high-quality production water ${ }^{[5]}$.

Another work from Malaysia used N-GET to remove pollutants in natural groundwater. N-GET on water quality performance of the system was designed for daily use in RECESS, UTHM. Parameters for all samples drawn were $\mathrm{pH}$, dissolved oxygen (DO), turbidity, manganese, chloride, nitrate, and sulfate. Water samples were passed through the N-GET system compared with drinking water quality standards in Malaysia by the Ministry of Health (KKM) [6].

\section{2 | MATERIAL AND METHOD}

The research method is a series of activities that are used as a reference for carrying out research.

\section{1 | Stage of prototype construction}

This stage is the prototype construction of groundwater treatment, which is conceptualized and tested. This water use aeration as pretreatment and central processing by filtration. At this stage, the water treatment technology variable is conceptualized. 


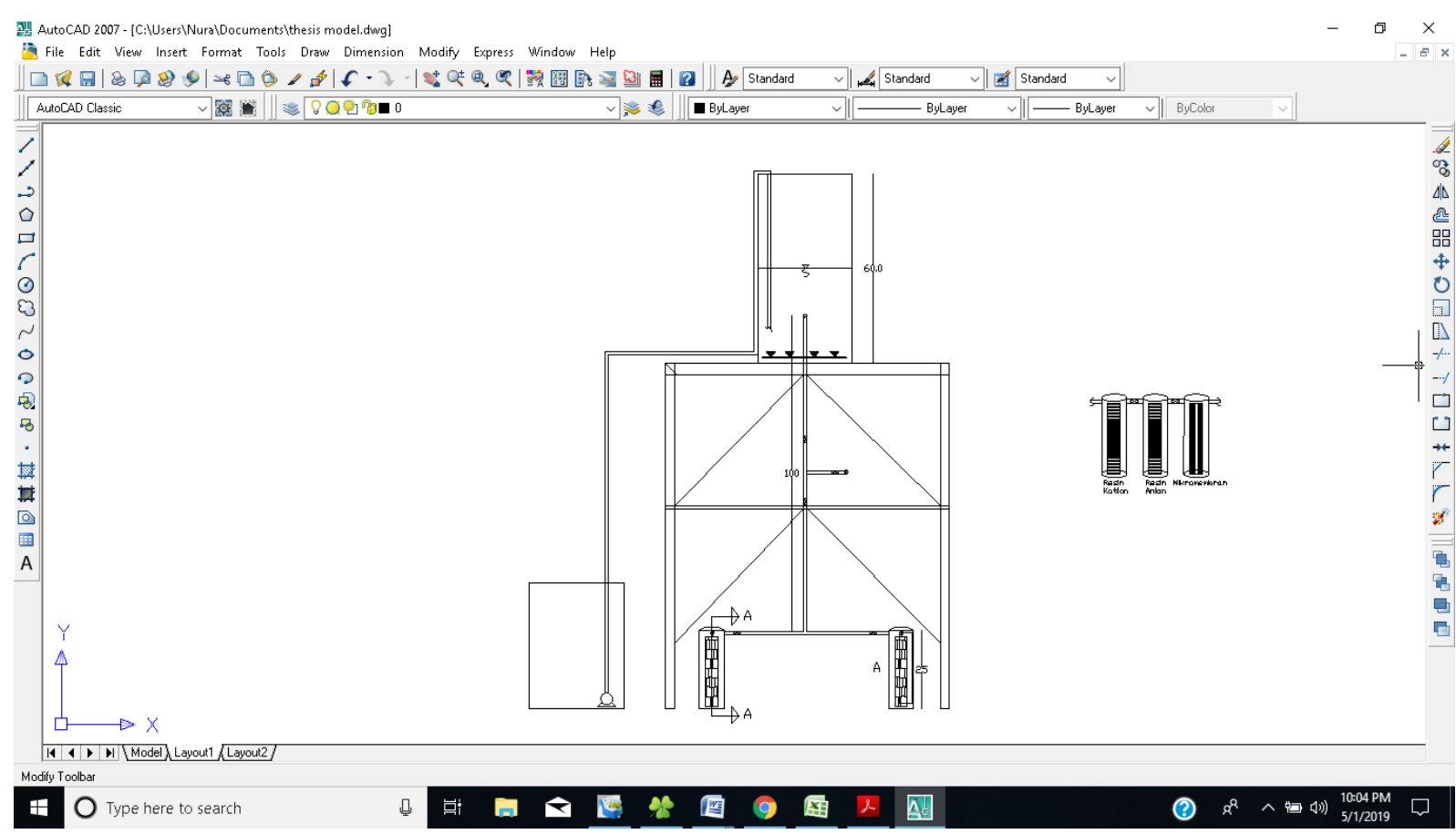

FIGURE 1 Aeration-Advanced Filtration (AAF) system.

TABLE 1 The groundwater characteristics.

\begin{tabular}{ccccc}
\hline$\#$ & Parameter & Unit & Water Control & Quality Standard \\
\hline 1 & Temperature & Celcius & 30.9 & air temperature \pm 3 \\
2 & pH & - & 7.8 & $6.5-8.5$ \\
3 & TDS & $\mathrm{mg} / \mathrm{L}$ & 8,800 & 500 \\
4 & Iron $(\mathrm{Fe})$ & $\mathrm{mg} / \mathrm{L}$ & 3.02 & 0.3 \\
5 & Chloride & $\mathrm{mg} / \mathrm{L}$ & 6,750 & 250 \\
\hline
\end{tabular}

\section{2 | Sampling and Test}

This stage is the implementation of the previous stage. Data collected includes primary data based on laboratory tests. Pretreatment processing will be carried out aeration technology based on criteria and designs based on previous research. Furthermore, the primary processing is carried out with multilevel filters with the adsorption process with activated carbon, resin, and microfiltration to remove water pollutants from the previous stage, namely dissolved ions, including chloride. This study uses an up-flow flow reactor with continuous discharge with enough pressure to make water through the filter.

This study's water sample was groundwater from deep ground wells (bore wells) from Rapadaya Village, Omben District, Sampang Regency. This study's deep groundwater is due to having an iron content of $>1 \mathrm{mg} / \mathrm{L}$ and chloride $>6000 \mathrm{mg} / \mathrm{L}$ with groundwater characteristics in Table 1.

This research was carried out on a laboratory scale. This process is carried out to determine the efficiency of reducing pollutants' concentration through physical-chemical methods using aeration. After an aeration process, filtration will be carried out with several media compositions. Groundwater samples were pumped into the AAF (control samples at the first tank), and samples of water that flows through each tank were compared to determine the treatment system's effectiveness.

\section{3 | Aeration}

Diffuser aeration technology was chosen in this study. The aeration process is carried out in aeration time (0-30 minutes), volume raw water is 40 liters be continued, the coarse bubble media is based on diffused aeration design criteria. Using this process, the quality of iron will decrease with the best increase in dissolved oxygen and determining the amount of air discharge needed. 


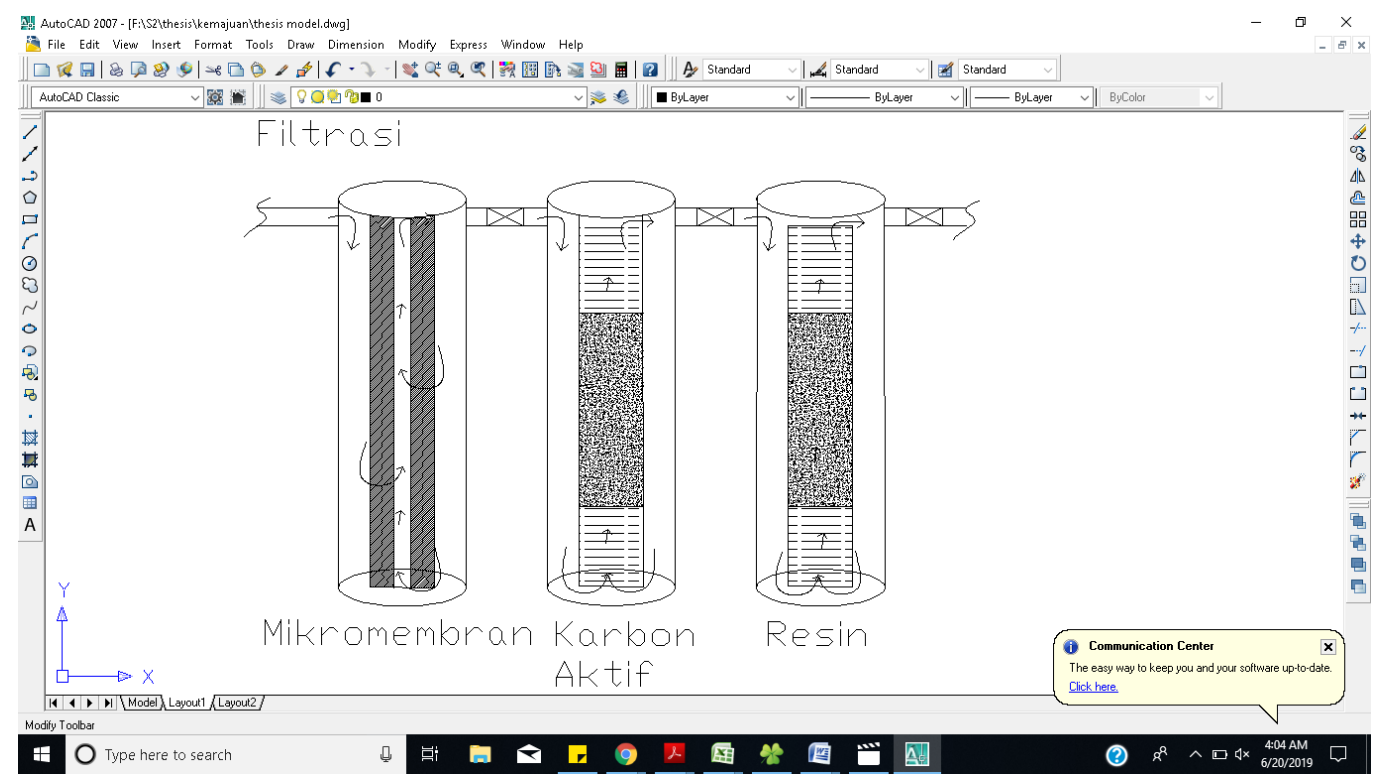

FIGURE 2 Piece A-A of advanced filtration for water treatment system.

Water treatment from the aeration-filtration process is illustrated in Figure 1. After the aeration process, the optimum results are obtained, followed by a multilevel filtration process. Aeration outlets are made in the middle (more up) so that the sediment during aeration so that the aeration process's deposition is not lifted.

\section{4 | Filtration}

This study uses a ready-made filter tool using different media compositions. The media used are anion resin, cation resin, and microfiltration. Types of media that can reduce dissolved ions. Anion Resin with Amberjet $4400 \mathrm{OH}-$ type Resin, Cation Resin with Amberjet $1200 \mathrm{H}+$ type and membrane-microfiltration propylene measuring 1 micron. The filter model is depicted in Figure 2. The filtration process is carried out from the aeration process. Then, the water is applied to the filter with a flow rate of $300 \mathrm{ml} / \mathrm{minute}$. The test results are carried out at the filtration outlet. Further, the effects of water filtration were tested in the laboratory. The multilevel filter in this study at each connection is equipped with valve settings for checking the quality between filters.

Based on the literature study, we determined the following variables for this study. The first variables, i.e. the independent variables in this study, are the factors that influence water treatment, namely, filter media. The second variable, i.e. the dependent variable, is the test variable influence of the independent variable. This research concentrates on water quality from the parameters carried out by analysis, namely temperature, Total Dissolved Solid (TDS), pH, iron, and chloride. The third variable, i.e. the controlled variable, is the variable specified. In this study, the aeration reactor and filter prototype were used.

The sample was taken in natural groundwater in Sampang, East Java, Indonesia. Sample can be used to over in the Ministry of Health (PerMenKes No. 492/2010) and showed in Table 1. Primary data collection is done through direct measurements on a prototype scale and parameter analysis in the Environmental Engineering Laboratory. Samples taken were analyzed based on Indonesian National Standards and Standard Methods for Examination of Water and Waste Water [AWWA, WPCF-APHA, 1995].

Technical analysis is technology selection, laboratory testing, and processes that occur during processing. This technical analysis obtained laboratory data from testing the prototype to be applied on a broader scale. This study uses laboratory analysis for the aeration process with aeration rate and oxygen capacity.

The determination of KLa of the setup according to the oxygen transfer capacities of the bioreactor. Different experimental techniques are used for determining this parameter. They can be classified into dynamic methods and stationary ones, both with or without reaction. The choice of the method depends on the experiments' goal, the practical constraints of implementation, 
and the type of reactor used. In this study, the dynamic method without a chemical reaction is used, where dissolved gas is transported into the liquid by molecular diffusion. The mass balance equation of oxygen is: with equations 7 .

$$
\frac{d C}{d t}=K L a(C s-C)
$$

where $\mathrm{KLa}$ is the total transfer coefficient, hour-1, Cs is the saturated gas concentration, $\mathrm{mg} / \mathrm{l}$, and $\mathrm{C}$ is gas concentration in liquid, $\mathrm{mg} / \mathrm{l}$.

The aerator for oxygen transfer is determined based on its oxygenation capacity (OC), which is defined as the aerator's rate of oxygen supply into clean water at conditions $\mathrm{C}, 1 \mathrm{~atm})$. Oxygenation Capacity (OC) standard (20॰C, $1 \mathrm{~atm})$. Oxygen capacity is formulated by Equation 1 or Equation 2.

$$
\begin{gathered}
O C=V \frac{d C}{d t} \\
O C=K L a C_{20} V
\end{gathered}
$$

The experimental data with the initial concentration of $\mathrm{Ci}$ oxygen and oxygen concentration in the $\mathrm{Ct}$ experiment time interval can be plotted ln (Cs-Ct) Vs t.

$$
\ln (C s-C t)=\ln (C s-C t)-K L a . t
$$

Then obtained a straight line with the magnitude of the direction (slope) is KLa in the equation above. With an initial condition of $\mathrm{t}=0, \mathrm{CL}=0$, the analytical solution.

$$
\ln \left(\frac{C s}{C s-C}\right)=K L a
$$

Besides that, the filtration process's technical analysis uses a continuous flow, and there are several filtrations through the ion exchange process with microfiltration resin and microfiltration. This filtration will calculate the filtration process efficiency from the inlet and outlet obtained.

\section{3 | RESULTS AND DISCUSSION}

The results of each experiment on the underground water parameters before treatment (control sample) and after treatment of aeration and filtration shown in the results.

\section{1 | Laboratory Phase}

The study carried out a diffused aeration process with bubble diffused aeration. This process checks the concentration of Dissolved Oxygen (DO) value and temperature in water treatment that the best time for diffuse aeration will be obtained. It showed that process is to batch diffuse aeration this study and continue in the water supply. The study of these parameters' influence on the variation of KLa is undertaken to establish a correlation between them. This correlation will be used in the prediction of the necessary oxygen amount.

Figure 3 shows the aeration in linear approximately. Table 2 shows the results of the temperature and dissolved oxygen (DO) value. The DO value before treated in the AAF was $4,7 \mathrm{mg} / \mathrm{L}$. It showed that DO saturation in temperature always a fluctuation in water supply in Table 2. Dissolved oxygen was upgraded to a better level. Continuously, it was selected after based on aeration experiments to advanced filtration.

After aeration treatment, the filtration process was reduced some of the pollutant concentrations of raw water to be processed. Filtration uses three filters, single, double filters, and three filters arranged in layers with three different media. Advanced filters have used membrane-microfiltration, activated carbon, and resin (Anion and Cation). 


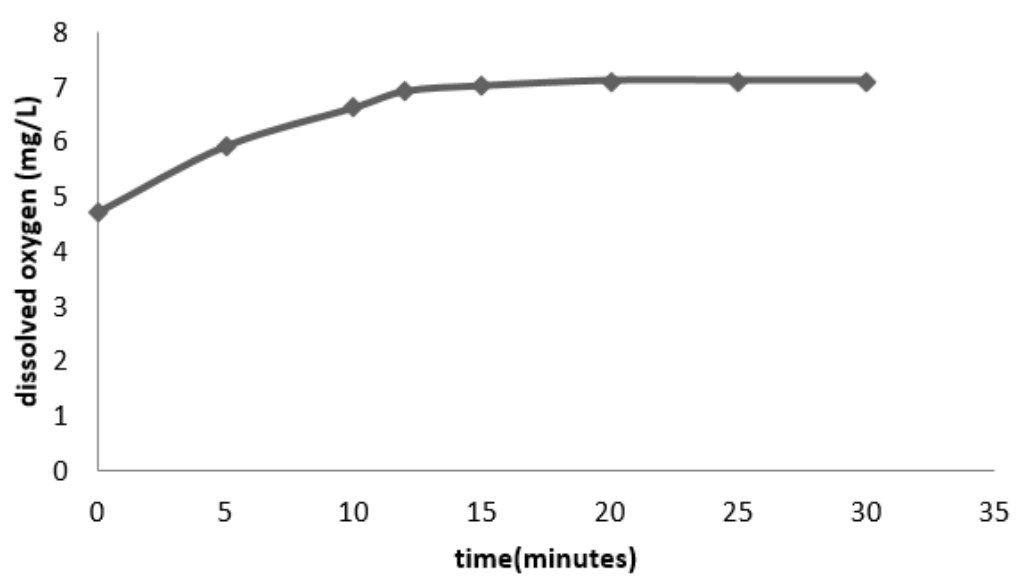

FIGURE 3 Linear approximation of the temporal evolution of dissolved oxygen concentration.

TABLE 2 Correlation dissolved oxygen and temperature in diffused aeration for water supply.

\begin{tabular}{cccc}
\hline$\#$ & $\begin{array}{c}\text { Period of Water } \\
\text { Supply After Aeration } \\
\text { (minutes) }\end{array}$ & $\begin{array}{c}\text { The concentration of } \\
\text { Dissolved Oxygen } \\
(\mathbf{m g} / \mathbf{L})\end{array}$ & Temperature $\left({ }^{\circ} \mathbf{C}\right)$ \\
\hline 1 & 0 & 6.2 & 34.7 \\
2 & 2 & 6.4 & 32.5 \\
3 & 5 & 6.6 & 31.1 \\
4 & 10 & 6.8 & 30.5 \\
5 & 15 & 6.8 & 30.7 \\
6 & 20 & 6.2 & 34.3 \\
7 & 30 & 6.8 & 30.3 \\
\hline
\end{tabular}

TABLE 3 Water control for aeration-advanced filtration in water treatment.

\begin{tabular}{cccccccc}
\hline \# & Parameter & Unit & Quality Standard & \multicolumn{3}{c}{ The outlet of Preliminary Water Treatment } \\
& & A & M & R & C \\
\hline 1 & Temperature & Celcius & air temperature \pm 3 & 30.9 & 30.9 & 32.6 & 31.5 \\
2 & pH & - & $6.5-8.5$ & 7.9 & 7.8 & $6,9-9,0$ & 8.5 \\
3 & TDS & mg/L & 500 & 8,180 & 7,570 & 437 & 7,780 \\
4 & Iron(Fe) & mg/L & 0.3 & 1.13 & 0.18 & 0.18 & 0.09 \\
5 & Chloride & mg/L & 250 & 6,750 & 6,450 & 240 & 6,650 \\
\hline
\end{tabular}

Water treatment by filtration in this study has used variations in filter types and media. Advanced filter in every media has determined the effectiveness of each medium to reduce pollutant concentration. The water treatment results in aeration, and filtration came from one process, i.e., an outlet with the same inlet treatment. This is shown in Table 3. Column A represents the diffused aeration. Column M represents the microfilration. Column $\mathrm{R}$ represents the filter of resin. Finally, column $\mathrm{C}$ represents the activated carbon filtration. The next process, after preliminary time detention, the water flow to the filter. In this filter, there were used media microfiltration, resin, and activated carbon. It results in Table 3. The results using cation-anion resin in filter media are more effective in decreasing TDS, Fe, and chloride, but if only using resin will be expensive, adding for aeration process as the preliminary process any media filter. It became resin, such as advanced treatment.

\section{2 | Effectiveness and Compared of AAF System in Quality Standards by the Ministry of Health}

The results of the technology of AAF. Based on Table 4, the technology of AAF completes media more than one or two media. TDS, Fe, and chloride reduced AAF treatment. Based on the content in Table 4, using aeration more effective for lowering TDS, chloride, and Fe, such as preliminary treatment. The result also using resin will be best reducing them. Microfiltration and activated carbon effectively reduce some pollutants, including Total Dissolved Oxygen (TDS) and iron. 
TABLE 4 The water quality of proposed aeration-advanced filtration.

\begin{tabular}{|c|c|c|c|c|c|c|}
\hline \# & Advanced Treatment & $\begin{array}{l}\text { Temperature } \\
\left({ }^{\circ} \mathbf{C}\right)\end{array}$ & ph & $\begin{array}{c}\text { TDS } \\
(\mathbf{m g} / \mathbf{L})\end{array}$ & $\begin{array}{c}\text { Iron } \\
(\mathbf{m g} / \mathbf{L})\end{array}$ & $\begin{array}{c}\text { Chloride } \\
\text { (mg/L) }\end{array}$ \\
\hline 1 & Ministry of Health (PerMenKes No. 492/2010) & $\begin{array}{l}\text { air temper- } \\
\text { ature } \pm 3\end{array}$ & $6.5-8.5$ & 500 & 0.3 & 250 \\
\hline 2 & Aeration- Activated Carbon Filtration (A-C) & 30.4 & 8.3 & 7900 & 0.045 & 6700 \\
\hline 3 & Aeration-Microfiltration Filtration (A-M) & 29.4 & 8 & 7900 & 0.04 & 6500 \\
\hline 4 & Aeration-Filter of Resin (A-R) & 31.2 & 7.3 & 432 & 0.04 & 350 \\
\hline 5 & $\begin{array}{l}\text { Aeration-(Activated Carbon-Microfiltration) } \\
\text { Filtration (A-C-M) }\end{array}$ & 32.7 & 8.1 & 8440 & 0.04 & 6200 \\
\hline 6 & $\begin{array}{l}\text { Aeration-(Microfiltration-Activated Carbon) } \\
\text { Filtration (A-M-C) }\end{array}$ & 32.4 & 8.1 & 8170 & 0.14 & 5900 \\
\hline 7 & $\begin{array}{l}\text { Aeration-(Activated Carbon-Resin) Filtration } \\
(\text { A-C-R) }\end{array}$ & 32.5 & 6.9 & 376 & 0.135 & 250 \\
\hline 8 & $\begin{array}{l}\text { Aeration-(Microfiltration-Resin) Filtration } \\
\text { (A-M-R) }\end{array}$ & 30.8 & 8 & 230 & 0.02 & 175 \\
\hline 9 & $\begin{array}{l}\text { Aeration-(Activated } \\
\text { Carbon-Microfiltration-Resin) Filtration } \\
\text { (A-C-M-R) }\end{array}$ & 33.6 & 7.5 & 286 & 0.075 & 250 \\
\hline 10 & $\begin{array}{l}\text { Aeration-(Microfiltration-Activated } \\
\text { Carbon-Resin) Filtration (A-M-C-R) }\end{array}$ & 33.4 & 7.1 & 256 & 0.035 & 175 \\
\hline
\end{tabular}

This microfiltration process is for separating particles with a maximum size of 1 micron. In a membrane separation process, particles are isolated on the premise of their molecular size and shape using an extraordinarily composed semi-permeable membrane. The semi-permeable membrane is frequently a thin, nonporous, or porous polymeric film, ceramic, or metal material or even a liquid or gas. The membrane must not dissolve, disintegrate or break ${ }^{8}$.

The use of activated carbon is the most effective method in controlling emissions from volatile organic compounds. Therefore, this study is also one of the most economical adsorptions. It uses activated carbon as the adsorbent. This process is cost-effective because it is typically able to recover many VOCs for reuse. But, in this study, activated carbon to remove ion iron too. However, the reduction in the ionization stage is less effective as it decreases chloride, so it requires a combination of filters with other media such as resin.

PerMenKes set the standard for chloride content was $250 \mathrm{mg} / \mathrm{L}$. Table 5 shows the experimental results for these parameters. Parameter chloride in groundwater showed the highest seen in $8800 \mathrm{mg} / \mathrm{L}$ before undergoing treatment. In based treatment in the system AAF treatment, only successfully removed chloride content for decreasing to $175 \mathrm{mg} / \mathrm{L}$ with $98 \%$ removal. However, the value obtained surpassed the limit PerMenKes.

This recommends that although chloride is a difficult parameter to be treated, AAF systems can produce water that meets quality standards. From the control samples $3.02 \mathrm{mg} / \mathrm{L}$, the content of Fe was removed by $63 \%$ in the AAF of $1.13 \mathrm{mg} / \mathrm{L}$. Improved removal was closer to PerMenKes standards had caused by particles that decomposed in the AAF. Based on the analyzed, to be chosen of treatment for removal of iron and chloride. Simultaneously, the content in Table 5 of total Dissolved Solid (TDS) showed potential in eliminating over $90 \%$. Iron and chloride also reduce more than $90 \%$, and these analyses show great potential in improving the removal, such as iron and chloride for AAF treatment. The percentage of Cl-ion removal decreases with the length of the process of the treatment. The length process treatment decreased up to $98 \%$ with an AAF in the completed media filter. According to the ion exchange reaction, this decrease can occur because the $\mathrm{OH}$ - ionic resin is saturated.

$$
\mathrm{R}-\mathrm{OH}^{-}+\mathrm{HCL} \rightarrow \mathrm{R}-\mathrm{CL}+\mathrm{H}_{2} \mathrm{O}
$$

$\mathrm{Cl}$ - ions replacing $\mathrm{OH}-$ ions in the resin until finally, the entire $\mathrm{OH}-$ ion is replaced by $\mathrm{Cl}$ - ions. At this time, a saturation process occurs, which results in stopping ion exchange resins. The duration of the sampling time is significant in the percentage allowance. The decrease in $\mathrm{Cl}$ - ion from the filtration process carried out at the filter outlet reaches a presets of over $90 \%$ to be effectively used. Cl- removal is more effective than combining AAF filters with aeration and filter of micro membrane-resins, reaching 98.39

AAF treatment system effectively treated and improved the quality of groundwater with stabilized the dissolved oxygen in aeration content. This treatment system also reduced the total dissolved solid values. Based on the overall variables observed, removing the parameter using aeration and filter of microfiltration, carbon active, and resin would produce more material. Thus, the results show that using aeration and filter of microfiltration and resin is effective because it can be reduced material the same. 
TABLE 5 The effectiveness of AFF treatment (TDS-, Fe-, and Cl-removal).

\begin{tabular}{|c|c|c|c|c|}
\hline \# & Advanced Treatment & TDS (\%) & $\mathrm{Fe}(\%)$ & $\mathrm{Cl}(\%)$ \\
\hline 1 & Aeration-Activated Carbon Filtration (A-C) & 10.23 & 96.37 & 0.74 \\
\hline 2 & Aeration-Microfiltration Filtration (A-M) & 10.23 & 96.77 & 3.70 \\
\hline 3 & Aeration-Filter of Resin (A-R) & 95.09 & 96.77 & 94.81 \\
\hline 4 & Aeration-(Activated Carbon-Microfiltration) Filtration (A-C-M) & 4.09 & 96.77 & 8.15 \\
\hline 5 & Aeration-(Microfiltration-Activated Carbon) Filtration (A-M-C) & 7.16 & 88.71 & 12.59 \\
\hline 6 & Aeration-(Activated Carbon-Resin) Filtration (A-C-R) & 95.73 & 89.11 & 96.30 \\
\hline 7 & Aeration-(Microfiltration-Resin) Filtration (A-M-R) & 97.39 & 98.39 & 97.41 \\
\hline 8 & Aeration-(Activated Carbon-Microfiltration-Resin) Filtration (A-C-M-R) & 96.75 & 93.95 & 96.30 \\
\hline 9 & Aeration-(Microfiltration-Activated Carbon-Resin) Filtration (A-M-C-R) & 97.09 & 97.18 & 97.41 \\
\hline
\end{tabular}

The effects of aeration and filtration processing (AAF) then analyzed the water quality to reach aeration, microfiltration, and resins with Cl-removal of 98.39\%, TDS allowance $97.394 \%$, and allowance for iron $97.41 \%$. The results after the research and analysis process, the pollutant concentration in groundwater was including the quality standard of the Regulation of the Ministry of Health RI. No. 492 of 2010 in TDS, iron, and chloride parameters.

\section{4 | CONCLUSION}

The conclusion of these studies was that the AAF treatment system effectively treated and improved groundwater quality with stabilized the dissolved oxygen in aeration content. This treatment system also reduced total Dissolved Solid values. The results of aeration and filtration processing (AAF) then analyzed the water quality on the overall variables observed, removed the parameter using effective aeration and filter of microfiltration, and resin. This treatment system eliminated parameters such as iron and chloride and improving the quality of groundwater. The water quality was undergone in this AAF system. It has passed the quality standards of drinking water supply by the Ministry of Health (PerMenKes no. 42 in 2010) and the raw water supply standards. Therefore, underground water that has been treated may be used for internal and external use in ITS. This study indicates that positive aspects of water treatment and drinking water supplies are as simple as a treatment system in the AAF system.

\section{References}

1. Widyastuti S, Sari AS. Kinerja Pengolahan Air Bersih Dengan Proses Filtrasi Dalam Mereduksi Kesadahan. Jurnal Teknik 2011;9(1):42-53.

2. Kusnaedi. Mengolah Air Kotor untuk Air Minum. Jakarta: Panebar Swadaya; 2010.

3. Peraturan Menteri Kesehatan Republik Indonesia Nomor 492/MENKES/PER/IV/2010, Kementrian Kesehatan Republik Indonesia, editor, Persyaratan Kualitas Air Minum. Jakarta: Kementrian Kesehatan Republik Indonesia; 2010.

4. Shamshuddin J, Anda M. Charge Properties of Soils in Malaysia Dominated by Kaolinite, Gibbsite, Goethite and Hematite. Bulletin of the Geological Society of Malaysia 2008;54:27-31.

5. Reynolds TD, Richards PA. Unit Operations and Processes in Environmental Engineering. 2 ed. Boston: PWS Publishing Company; 1995.

6. Musa S, Denan F, Hamdan R, Radin Mohamed S. Natural Groundwater Eco-Treatment (N-GET) for Water Supply at Johor, Malaysia. Journal of Advanced Research in Fluid Mechanics and Thermal Sciences 2015;9(1):19-27.

7. Zamouche R, Bencheikh-Lehocine M, Meniai AH. Oxygen Transfer and Energy Savings in A Pilot-Scale Batch Reactor for Domestic Wastewater Treatment. Desalination 2007 feb;206(1-3):414-423.

8. Seadar JD, Heneley JE. Separation Process Principles. 2 ed. Hoboken,New Jersey: John Wiley \& Sons, Inc; 2005. 
How to cite this article: Giandi O., Irawan I., Ambarwati R., (2020), Aeration - Advanced Filtration (AAF) Treatment for Reducing Iron and Chloride in Natural Groundwater, IPTEK The Journal of Technology and Science, 31(2):169-177. 